\title{
Molecular Profiling in IgA Nephropathy and Focal and Segmental Glomerulosclerosis
}

\author{
I. TYCOVÁ ${ }^{1^{*}}$, P. HRUBÁ ${ }^{1^{*}}$, D. MAIXNEROVÁ ${ }^{2}$, E. GIRMANOVÁ ${ }^{1}$, P. MRÁZOVÁ ${ }^{1}$, \\ L. STRAŇAVOVÁ ${ }^{1}$, R. ZACHOVAL ${ }^{3}$, M. MERTA ${ }^{2}$, J. SLATINSKÁ ${ }^{5}$, M. KOLLÁR $^{4}$, \\ E. HONSOVÁ ${ }^{4}$, V. TESAŘ $\check{2}^{2}$, O. VIKLICKÝY ${ }^{1,5}$ \\ * These authors contributed equally to this work.
}

${ }^{1}$ Transplant Laboratory, Institute for Clinical and Experimental Medicine, Prague, Czech Republic, ${ }^{2}$ Department of Nephrology Charles University and General University Hospital in Prague, First Faculty of Medicine, Czech Republic, ${ }^{3}$ Department of Urology Thomayer University Hospital, Prague, Czech Republic, ${ }^{4}$ Department of Clinical and Transplant Pathology, Institute for Clinical and Experimental Medicine, Prague, Czech Republic, ${ }^{5}$ Department of Nephrology, Institute for Clinical and Experimental Medicine, Prague, Czech Republic

Received May 25, 2017

Accepted August 1, 2017

On-line November 10, 2017

\section{Summary}

The aim of the study was to characterize by molecular profiling two glomerular diseases: IgA nephropathy (IgAN) and focal segmental glomerulosclerosis (FSGS) and to identify potential molecular markers of IgAN and FSGS progression. The expressions of 90 immune-related genes were compared in biopsies of patients with IgAN $(n=33)$, FSGS $(n=17)$ and in controls ( $n=11$ ) using RT-qPCR. To identify markers of disease progression, gene expression was compared between progressors and non-progressors in 1 year follow-up. The results were verified on validation cohort of patients with IgAN $(n=8)$ and in controls $(n=6)$ using laser-capture microdissection, that enables to analyze gene expression separately for glomeruli and interstitium. In comparison to controls, patients with both IgAN and FSGS, had lower expression of BAX (apoptotic molecule BCL2-associated protein) and HMOX-1 (heme oxygenase 1) and higher expression of SELP (selectin P). Furthermore, in IgAN higher expression of PTPRC (protein-tyrosine phosphatase, receptor-type C) and in FSGS higher expression of BCL2L1 (regulator of apoptosis BCL2-like 1) and IL18 compared to control was observed. Validation of differentially expressed genes between IgAN and controls on another cohort using laser-capture microdissection confirmed higher expression of PTPRC in glomeruli of patients with IgAN. The risk of progression in IgAN was associated with higher expression EDN1 (endothelin 1)
$(A \cup C=0.77)$ and FASLG (Fas ligand) $(A \cup C=0.82)$ and lower expression of VEGF (vascular endothelial growth factor) $(A \cup C=0.8)$ and in FSGS with lower expression of CCL19 (chemokine (C-C motif) ligand 19) (AUC=0.86). Higher expression of EDN1 and FASLG along with lower expression of VEGF in IgAN and lower expression of CCL19 in FSGS at the time of biopsy can help to identify patients at risk of future disease progression.

\section{Key words}

IgA nephropathy - Focal segmental glomerulosclerosis - Gene expression

\section{Corresponding author}

P. Hruba, Transplant Laboratory, Institute for Clinical and Experimental Medicine, Videnska 1958/9, 14021 Prague, Czech Republic. Fax: +420 261353 168. E-mail: petra.hruba@ikem.cz

\section{Introduction}

IgA nephropathy (IgAN) and focal segmental glomerulosclerosis (FSGS) are considered to be the most common glomerulopathies which in significant part of patients progress into end stage renal disease (ESRD) (Coppo et al. 2010, Moriyama et al. 2014). The 
pathophysiology of the disease progression remains poorly understood.

Besides classical histopathological diagnostics (Chandramohan et al. 2009, Schmitt et al. 2014), molecular microscope may better evaluate dynamic molecular events which may be involved in the disease and progression pathogenesis.

Among well-known predictors of IgAN progression belong sustained hypertension, impaired renal function and persistent proteinuria $(>1 \mathrm{~g} / \mathrm{d})$. The Oxford classification identified four pathological features (mesangial hypercellularity, endocapillary hypercellularity, segmental glomerulosclerosis, and tubular atrophy/ interstitial fibrosis, resulting in a MEST score) that predicted renal outcome (Roberts et al. 2009). VALIGA study validated MEST score on 1,147 patients and showed that histological signs of chronic and irreversible damage (mesangial hypercellularity, segmental sclerosis, and tubular atrophy/interstitial fibrosis) had the strongest association with unfavorable outcome (Barbour et al. 2016, Coppo et al. 2014).

To date, three key molecules were found to be associated with progression of IgAN disease progression/recurrence after transplantation: galactosedeficient IgA1 (Gd-IgA1), IgG anti-Gd-IgA1 antibodies, and soluble CD89 (an Fc receptor for IgA) (Moldoveanu et al. 2007, Robert et al. 2015). Several studies identified numerous urinary biomarkers of progression of IgAN such as epidermal growth factor (Stangou et al. 2009), monocyte chemoattractant protein-1 (MCP-1), complement ( $\mathrm{C} 3 \mathrm{a}$ and $\mathrm{C} 5 \mathrm{a}$ ) or chemokine (C-X-C motif) ligand 1 (CXCL1) (Zhao et al. 2015).

In FSGS, the increased serum creatinine, proteinuria, interstitial fibrosis and the presence of collapsing lesions were shown to be predictive for the progression into ESRD (Schwartz et al. 1999). The role of T-cell costimulating molecule B7-1 (CD80) in development of proteinuria in FSGS patients has been described (Kronbichler et al. 2016). Higher expression of some molecular markers of podocytes (podoplanin and podocin) were found in FSGS (Koop et al. 2003) and recently, it was shown that collapsing variant of FSGS with the worst prognosis had lower immunohistochemical expression of podocyte markers (CD10, $\alpha$-actinin-4, and WT1) (Testagrossa et al. 2013).

In this study, we aimed to better characterize molecular profiles of IgAN and FSGS and to identify potential molecular markers for the disease progression. Such markers might help to guide more specific and aggressive therapy for patients at risk.

\section{Methods}

\section{Study cohort}

Fifty patients in whom $\operatorname{IgAN}(\mathrm{n}=33)$ or FSGS $(n=17)$ was histologically diagnosed in 2 nephrology centers between January 2005 and May 2007 were prospectively enrolled in the study and followed for 12 months. The study protocol was approved by the Ethics Committee of the Institute for Clinical and Experimental Medicine in Prague (No. A 13-02-01) and General Teaching hospital in Prague (No. 19/06). Clinical and laboratory data were collected on the date the biopsy was performed and same data also one year after the biopsy. Patient demographic and clinical data are summarized in Table 1.

Control group consisted of eleven renal samples taken from "healthy" part of kidney in patients with renal cancer. All samples were taken during surgery, before beginning of renal cancer therapy to avoid the influence of anti-cancer drugs on the gene expression. Five males and 6 females were included to control group with the median age at the time of sampling 71.0 (44.0-81.0) years, the median body mass index (BMI) 27.5 $(19.6-35.3) \mathrm{kg} / \mathrm{m}^{2}$ and the median level of serum creatinine 90.0 (62.0-126.0) $\mu \mathrm{mol} / \mathrm{l}$.

Based on the disease progression during the 12 month follow-up after kidney biopsy, two patient subgroups were identified. Patients in whom serum creatinine at 12-months increased for more than $20 \%$ of baseline values or in whom the disease proceeded to ESRD were classified as "progressors. Patients in whom serum creatinine decreased during the 12-month followup or remained stable within normal range were classified as "non-progressors" (Table 2).

\section{Validation cohort}

As a validation cohort, samples from patients with $\operatorname{IgAN}(n=8)$ and controls $(n=6)$ were enrolled between October 2013 and June 2015. Control samples were taken from "healthy" part of kidney in patients with renal cancer. Patients in the control group had median age at the time of sampling $71.8(40.7-80.4)$ and from IgAN group 39.3 (25-63.6) years. 
Table 1. Patients demographic and clinical data.

\begin{tabular}{|c|c|c|c|}
\hline & IgAN Group & FSGS Group & *p value \\
\hline \multicolumn{4}{|l|}{ Biopsy time point } \\
\hline$N$ & 33 & 17 & \\
\hline Male (\%) & 61 & 71 & 0.548 \\
\hline Age (years) & $38.6(19.3 ; 65.6)$ & $48.5(25.0 ; 77.0)$ & 0.103 \\
\hline$B M I\left(\mathrm{~kg} / \mathrm{m}^{2}\right)$ & $24.2(19.9 ; 43.3)$ & $26.8(20.2 ; 39.5)$ & 0.559 \\
\hline Creatinine $(\mu \mathrm{mol} / \mathrm{l})$ & $124.0(64.0 ; 528.0)$ & $81.0(60.0 ; 400.0)$ & 0.062 \\
\hline$G F R(\mathrm{ml} / \mathrm{s})$ & $1.05(0.18 ; 3.01)$ & $1.37(0.23 ; 2.59)$ & 0.089 \\
\hline Proteinuria (g/day) & $1.48(0.08 ; 15.15)$ & $4.51(0.88 ; 11.26)$ & $0.010^{*}$ \\
\hline Erythrocyturia (\%) & 75 & 65 & 0.511 \\
\hline Serum $\operatorname{Ig} A(g / l)$ & $2.50(1.17 ; 6.40)$ & $1.93(0.93-2.87)$ & $0.034^{*}$ \\
\hline Systolic blood pressure (mm Hg) & $140(120 ; 220)$ & $140(110 ; 180)$ & 0.713 \\
\hline Diastolic blood pressure ( $\mathrm{mm} \mathrm{Hg}$ ) & $85(70 ; 120)$ & $90(70 ; 122)$ & 0.827 \\
\hline Cholesterol $(\mathrm{mmol} / \mathrm{l})$ & $5.20(2.73 ; 11.30)$ & $5.90(3.08 ; 15.7)$ & 0.180 \\
\hline Triglycerides $(\mathrm{mmol} / \mathrm{l})$ & $1.73(0.44 ; 5.66)$ & $2.36(1.02 ; 6.11)$ & $0.031 *$ \\
\hline \multicolumn{4}{|l|}{ Therapy before biopsy } \\
\hline Prednisone / CPA (\%, (n)) & $3(1)$ - prednisone & 0 & 1.000 \\
\hline$A C E i$ and/or $A R B(\%)$ & 48 & 63 & 0.372 \\
\hline \multicolumn{4}{|l|}{ Therapy after biopsy } \\
\hline Prednisone/CPA (\%) & 67 & 47 & 0.229 \\
\hline Prednisone alone (\%) & 59 & 100 & \\
\hline Prednisone + cyclophosphamide (\%) & 41 & 0 & 0.067 \\
\hline$A C E i$ and/or $A R B$ & 85 & 100 & 0.152 \\
\hline \multicolumn{4}{|l|}{ 12-month follow-up } \\
\hline$N$ & 32 ( 1 exitus $)$ & 16 (1 exitus) & \\
\hline Creatinine $(\mu \mathrm{mol} / \mathrm{l})$ & $116.7(73.0 ; 600.0)$ & $97.0(77.0 ; 294.0)$ & 0.186 \\
\hline$G F R(\mathrm{ml} / \mathrm{s})$ & $1.12(0.01 ; 2.40)$ & $1.28(0.70 ; 2.89)$ & 0.144 \\
\hline Proteinuria (g/day) & $0.54(0.00 ; 7.68)$ & $0.8(0.05 ; 5.07)$ & 0.709 \\
\hline Prednisone/CPA (\%) & 38 & 50 & 0.537 \\
\hline Prednisone alone (\%) & 92 & 100 & \\
\hline Prednisone + cyclophosphamide (\%) & 8 & 0 & 1.000 \\
\hline$A C E i$ and/or $A R B(\%)$ & 94 & 100 & 0.546 \\
\hline
\end{tabular}

Data are shown as medians (minimum-maximum). $* \mathrm{p}-$ values for categorical data were calculated by the Fisher's test and for continuous variables by Mann-Whitney test.

\section{Renal biopsy}

All biopsies were performed using a 14- or 16-gauge Tru-Cut needle (Uni-Cut Nadeln, Angiomed, Germany) guided by ultrasound (Toshiba, Power Vision 6000 , Japan. Small portions $(\sim 2 \mathrm{~mm})$ of renal tissue from the cortical zone were immediately stored in preserve solution (RNA later, Qiagen) for expression analysis, while the majority of renal tissue taken by core biopsy was used for routine histology performed by the standard method. Samples were routinely stained with haematoxylin and eosin, haematoxylin and eosin with elastic stain, periodic acid-Schiff (PAS), aldehydefuchsin orange $G$ (AFOG), Sirius red with elastic stain and periodic acid silver-methenamine (PASM).

\section{RNA isolation}

Renal tissue was homogenized, total RNA was extracted using RNA Blue (Top-Bio s.r.o. Czech Republic) and reverse transcribed into complementary DNA (cDNA), as described elsewhere (Platzer et al. 1994). 
Table 2. Demographic and clinical data of progressors and non-progressors.

\begin{tabular}{|c|c|c|c|}
\hline & \multicolumn{2}{|c|}{ IgAN Group } & \multirow[b]{2}{*}{ * p value } \\
\hline & Non-progressors & Progressors & \\
\hline \multicolumn{4}{|l|}{ Biopsy time point } \\
\hline$N$ & 21 & 7 & \\
\hline Age (years) & $36(19 ; 58)$ & $45(28 ; 65)$ & 0.326 \\
\hline$B M I\left(\mathrm{~kg} / \mathrm{m}^{2}\right)$ & $24(21 ; 40)$ & $33(25 ; 36)$ & 0.395 \\
\hline Creatinine $(\mu \mathrm{mol} / \mathrm{l})$ & $124(75 ; 528)$ & $335(64 ; 471)$ & 0.799 \\
\hline$G F R(\mathrm{ml} / \mathrm{s})$ & $1.13(0.2 ; 3)$ & $0.3(0.18 ; 1.3)$ & 0.610 \\
\hline Proteinuria (g/day) & $1.3(0.1 ; 15.1)$ & $4.5(0.4 ; 5.5)$ & 0.628 \\
\hline Serum $\operatorname{Ig} A(g / l)$ & $2.2(1.2 ; 4.7)$ & $4(2.1 ; 5.1)$ & 0.250 \\
\hline \multicolumn{4}{|l|}{ 12-month follow-up } \\
\hline Creatinine $(\mu \mathrm{mol} / \mathrm{l})$ & $113.3(73 ; 541)$ & $460(83 ; 600)$ & 0.899 \\
\hline$G F R(\mathrm{ml} / \mathrm{s})$ & $1.2(0.5 ; 1.9)$ & $0.9(0 ; 2.4)$ & 0.898 \\
\hline Proteinuria (g/day) & $0.5(0 ; 7.7)$ & $1.4(0.2 ; 2.7)$ & 0.793 \\
\hline \multicolumn{4}{|l|}{ 24-month follow-up } \\
\hline Creatinine $(\mu \mathrm{mol} / \mathrm{l})$ & $116.5(70 ; 225)$ & $600(80 ; 600)$ & 0.399 \\
\hline$G F R(\mathrm{ml} / \mathrm{s})$ & $1.4(0.4 ; 3)$ & $0.5(0 ; 1.5)$ & 0.954 \\
\hline Proteinuria (g/day) & $0.4(0 ; 1.8)$ & $1(0.1 ; 1.4)$ & 0.433 \\
\hline \multirow[t]{3}{*}{ Transplantation/Dialysis by 2 years (n, \%) } & $1(4.8 \%)$ & $4(57.1 \%)$ & 0.075 \\
\hline & \multicolumn{2}{|c|}{ FSGS Group } & \\
\hline & Non-progressors & Progressors & * p value \\
\hline \multicolumn{4}{|l|}{ Biopsy time point } \\
\hline$N$ & 9 & 4 & \\
\hline Age (years) & $49(25 ; 77)$ & $34(31 ; 66)$ & 0.537 \\
\hline$B M I\left(\mathrm{~kg} / \mathrm{m}^{2}\right)$ & $28(21 ; 40)$ & $23(20 ; 29)$ & 0.064 \\
\hline Creatinine $(\mu \mathrm{mol} / \mathrm{l})$ & $81(71 ; 384)$ & $88(60 ; 114)$ & 0.279 \\
\hline$G F R(\mathrm{ml} / \mathrm{s})$ & $1.4(0.4 ; 2.6)$ & $1.4(0.7 ; 1.9)$ & 0.877 \\
\hline Proteinuria (g/day) & $4.6(1.5 ; 2.1)$ & $6.3(0.9 ; 11.3)$ & 0.758 \\
\hline \multicolumn{4}{|l|}{ 12-month follow-up } \\
\hline Creatinine $(\mu \mathrm{mol} / \mathrm{l})$ & $82(77 ; 274)$ & $111(83 ; 153)$ & 0.537 \\
\hline$G F R(\mathrm{ml} / \mathrm{s})$ & $1.4(0.6 ; 2.9)$ & $1.1(0.7 ; 1.9)$ & 0.440 \\
\hline Proteinuria (g/day) & $0.8(0.2 ; 5.1)$ & $0.9(0.1 ; 1.3)$ & 0.610 \\
\hline \multicolumn{4}{|l|}{ 24-month follow-up } \\
\hline Creatinine $(\mu \mathrm{mol} / \mathrm{l})$ & $86(72 ; 239)$ & $99(64 ; 120)$ & 0.877 \\
\hline$G F R(\mathrm{ml} / \mathrm{s})$ & $1.4(0.7 ; 2.9)$ & $1.3(0.7 ; 2.3)$ & 0.877 \\
\hline Proteinuria (g/day) & $0.4(0 ; 6.6)$ & $0.9(0.3 ; 3.1)$ & 0.438 \\
\hline Transplantation/Dialysis by 2 years ( $n, \%)$ & 0 & 0 & \\
\hline
\end{tabular}

* p values for categorical data were calculated by Fisher's test and for continuous variables by Mann-Whitney test.

$R T-q P C R$

Gene expression profile of 90 targets (Human
Immune Panel, Applied Biosystems CA, USA) known to have implications in immune response (cytokines, 
costimulatory molecules and growth factors chemokines, immune regulators, apoptosis markers, ischemia markers) was determined using RT-qPCR $\left(2^{-\Delta \Delta C t}\right)$ method with GAPDH as internal control and cDNA from a control kidney serving as the calibrator in 61 renal biopsy specimens. All evaluated genes are shown in Table 3. Each immune profiling TLDA contains lyophilized gene expression reagents (primers and probes [FAM labelled]) in a preconfigured 384 well format.

Table 3. Genes evaluated by RT-qPCR.

\begin{tabular}{|c|c|c|c|}
\hline$I L 1 A$ & $C D 40$ & $G Z M B$ & $I L 9$ \\
\hline $18 S$ & $C D 40 L G$ & $H L A-D R A$ & $L R P 2$ \\
\hline$A C E$ & $C D 68$ & $H L A-D R B 1$ & $L T A$ \\
\hline$A C T B$ & $C D 80$ & $H M O X 1$ & МYH6 \\
\hline AGTR1 & $C D 86$ & $I C A M 1$ & $N F K B 2$ \\
\hline$A G T R 2$ & $C D 8 A$ & $I C O S$ & $N O S 2 A$ \\
\hline$B A X$ & COL4A5 & $I F N G$ & PGK1 \\
\hline$B C L 2$ & CSF1 & $I K B K B$ & PRF1 \\
\hline$B C L 2 L 1$ & $C S F 2$ & IL10 & PTGS2 \\
\hline C3 & $C S F 3$ & $I L 12 A$ & PTPRC \\
\hline CCL19 & CTLA4 & $I L 12 B$ & $R E N$ \\
\hline CCL2 & CXCL10 & IL13 & $R P L 3 L$ \\
\hline CCL3 & CXCL11 & IL 15 & SELE \\
\hline CCL5 & $C X C R 3$ & IL17 & SELP \\
\hline$C C R 2$ & CYP1A2 & IL18 & $S K I$ \\
\hline CCR4 & CYP7A1 & $I L 1 B$ & $S M A D 3$ \\
\hline CCR5 & ECE1 & IL2 & SMAD7 \\
\hline CCR7 & EDN1 & $I L 2 R A$ & STAT3 \\
\hline$C D 19$ & $F A S$ & $I L 3$ & $T B X 21$ \\
\hline$C D 28$ & $F A S L G$ & IL4 & $T F R C$ \\
\hline$C D 34$ & FN1 & IL5 & $T G F B 1$ \\
\hline$C D 38$ & GAPDH & IL6 & $T N F$ \\
\hline$C D 3 E$ & $G N L Y$ & $I L 7$ & TNFRSF 18 \\
\hline$C D 4$ & GUSB & IL8 & $V E G F$ \\
\hline
\end{tabular}

Gene symbols frequently used as housekeeping genes are in bold. According the geNorm and NormFinder softwares the GAPDH as internal control for this study was chosen.

Two samples in duplicate were analyzed per card. Each loading port was filled with a $100 \mu$ l volume containing cDNA, nuclease free water and TaqMan ${ }^{\circledR}$ universal PCR master mix $(2 \times)$. Following centrifugation, cards were sealed with a TLDA sealer (Applied Biosystems, CA, USA) to prevent cross contamination. Real time RT-PCR amplification was performed on an ABI Prism ${ }^{\circledR} 7900$ H.T. Sequence Detection system (Applied Biosystems, CA, USA).

TLDA cards were analyzed as relative quantification (RQ) and RQ manager 1.2.software for automated data analysis was used (Applied Biosystems, CA, USA).
Laser-capture microdissection

In a validation cohort, laser-capture microdissection a small portion $(\sim 2 \mathrm{~mm})$ of renal tissue was embedded into Tissue-Tec immediately after biopsy or after surgery in case of nephrectomy, frozen with liquid nitrogen and stored at $-80{ }^{\circ} \mathrm{C}$. To ensure the similarities between sample takings, the biopsy needle was used also to take the samples from kidneys after nephrectomy. The samples were cut to $10-\mu \mathrm{m}$-thick sections on a cryotome at $-20{ }^{\circ} \mathrm{C}$. Sections were mounted onto RNAse free MMI Membrane Slides (MMI AG, Glattbrugg, Switzerland) and immediately fixed in $96 \%$ ethanol for $45 \mathrm{~s}$. After removal of Tissue Tec in $70 \%$ ethanol, slides were stained in haematoxylin for $45 \mathrm{~s}$, rinsed in RNAse free water, counterstained by eosin for $30 \mathrm{~s}$, rinsed in RNAse 
free water and fixed in $96 \%$ ethanol for $45 \mathrm{~s}$ (H\&E staining kit plus (MMI AG, Glattbrugg, Switzerland). Slides were then air-dried for $30 \mathrm{~s}$ and immediately microdissected on MMI CellCut ${ }^{\circledR} \quad$ (Molecular Machines\&Industries, Zürich, Switzerland). Microdissection time did not exceed $30 \mathrm{~min}$ to avoid the action of RNAases. Glomeruli (for each patient the area $1.08 \mathrm{~mm}^{2}$ [range 0.37-3.16] corresponding to 9-96 glomeruli) or interstitium (for each patient the area of $2.9 \mathrm{~mm}^{2}$ of tissue [range 0.65-4.10]) were marked, cut automatically using an UV-Laser, collected on the adhesive cap, put directly into the lysis buffer for RNA isolation (RLT, RNeasy Micro Kit, Qiagen) and stored at $-20^{\circ} \mathrm{C}$ until isolation. RNA was isolated using the RNeasy Micro Kit (Qiagen) according to the manufacturer's instructions. RNA concentration was determined using Agilent RNA 6000 Pico Kit on the Agilent 2100 BioAnalyzer.

RNA was reverse transcribed into cDNA using Superscript Reverse Transcriptase II (Invitrogen). Quantitative RT-PCR was performed using Taqman gene expression assays with a fast protocol as described elsewhere (Viklicky et al. 2013). Genes that were identified as differentially expressed between IgAN and control (BAX-Hs00180269_m1, HMOX1Hs00157965_m1, PTPRC-Hs04189704_m1, SELPHs00174583_m1), WT1-Hs01103751_m1 (as gene with glomerulus specific expression) and GAPDHHs99999905_m1 (as endogenous control) were measured for each sample in triplicate, separately for glomeruli and interstitium. As a calibrator, one sample of glomeruli from control group with good expression profile on all of target genes was chosen. The samples with less than $50 \%$ measurable genes were excluded from analysis.

\section{Statistical analysis}

Differences in mRNA expression or clinical parameters between groups were analyzed using the Mann-Whitney or Kruskal-Wallis statistic with Dunn's Multiple Comparison test. The area below the receiver operating characteristic (ROC) curve was performed to estimate the cut-off value of different transcripts for disease progression. A $\mathrm{p}<0.05$ was considered to be statistically significant.

Supervised hierarchical clustering was performed with the $\mathrm{MeV}$ (V.3) software in order to visualize the results. Statistical analyses were performed using SPSS v.20.0 (SPSS, Inc., Chicago, IL, USA) and GraphPad InStat v. 3.05 for Windows (GraphPad software, San Diego, CA, USA).

\section{Results}

Differences in gene expression profiles of IgAN, FSGS and control

Hierarchical clustering (Fig. 1) indicated that IgAN, FSGS group and control group differ in immune gene expression profiles. Clustering showed gene expression profiles of normal controls and IgAN group are similar and form a cluster; by contrast gene expression profile of FSGS group differs. Gene patterns forming a cluster are more closely related to one another than objects assigned to different cluster.

Patients suffering from FSGS had reduced gene expression of apoptotic molecule BCL2-associated $\mathrm{x}$ protein $(B A X)(\mathrm{p}<0.001)$ and cytoprotective factor with anti-inflammatory and antioxidant effects heme oxygenase $1(H M O X-1)(\mathrm{p}<0.001)$ compared with control group. On the other hand there was increased expression of another regulator of apoptosis BCL2-like 1 (BCL2L1) $(\mathrm{p}<0.01)$, product of macrophages interleukin 18 (interferon-gamma-inducing factor, IL18) $(\mathrm{p}<0.05)$ and adhesion molecule selectin $\mathrm{P}$ (SELP, antigen CD62) $(\mathrm{p}<0.05)$ in a group with FSGS (Fig. 2). Similarly, patients with $\operatorname{IgAN}$ have also reduced intrarenal gene expression of $B A X \quad(\mathrm{p}<0.01)$ and HMOX-1 $(\mathrm{p}<0.01)$ compared to the control group. Furthermore, these patients have a significantly increased protein-tyrosine phosphatase, receptor-type, C $(P T P R C)(\mathrm{p}<0.05)$ and SELP $(\mathrm{p}<0.05)$ gene expression (Fig. 2) which shows a strong mononuclear infiltration of the tissue.

\section{RT-qPCR of RNA from microdissected glomeruli and interstitium}

In the validation cohort, genes with significantly different expression were selected and analyzed separately for glomeruli and interstitium using lasercapture microdissection.

When compared gene expression between glomeruli and interstitium in all samples, significant higher expression in glomeruli was found for WT1 $(\mathrm{p}<0.001)$, PTRPRC $(\mathrm{p}=0.02)$ and significant higher expression in interstitium for HMOX-1 ( $\mathrm{p}=0.036)$ (Fig. 3A). WT1 gene was selected as a molecular marker of glomerular podocytes. When compared IgAN patients and controls trends to higher expression of PTPRC and $H M O X-1$ in glomeruli were observed in $\operatorname{IgAN}$ group $(\mathrm{p}=0.053$, $\mathrm{p}=0.068$, respectively) (Fig. $3 \mathrm{~B}$ ). The expression of two remaining genes found to be differentially expressed between IgAN patients and controls $(B A X, S E L P)$ did differ neither in glomeruli nor in interstitium. 


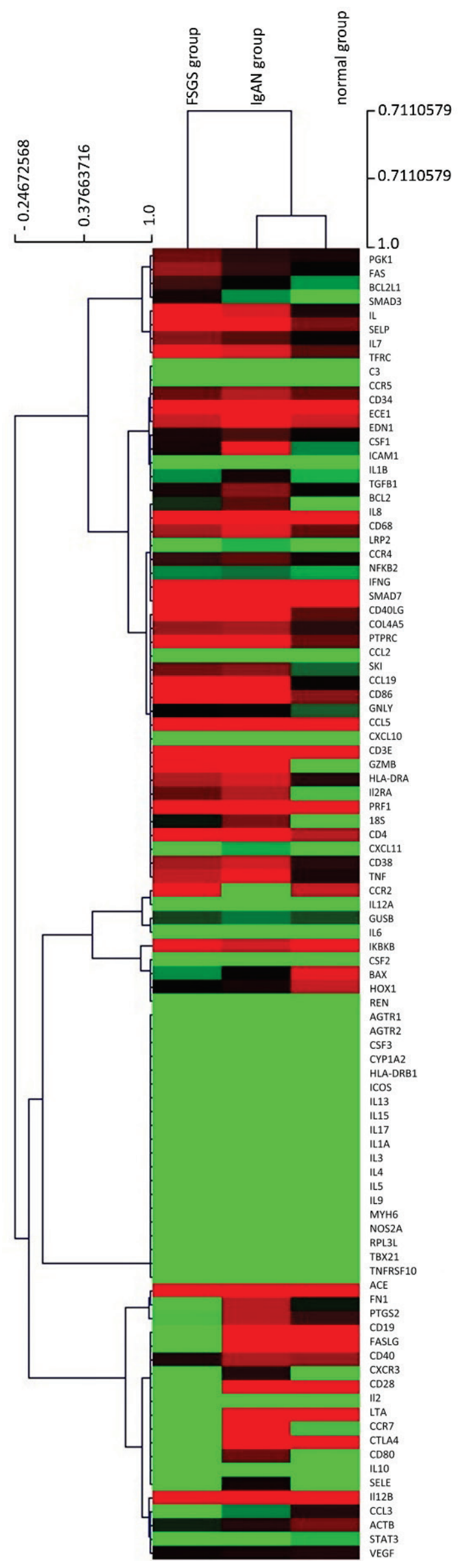

Fig. 1. Supervised hierarchical clustering of 90 immune related genes expression profiles in controls, IgAN and FSGS group. Spearman's rank correlation was used as the distance measure for average linkage clustering. Controls and IgAN group are similar and form a cluster, by contrast gene expression profile of FSGS group differs.

\section{Progression associated genes}

For determination of the risk for $\operatorname{IgAN}$ and FSGS progression in dependence of renal gene expression during the 12 months follow-up after kidney biopsy the ROC analysis were designed and the critical cut-off points were adjusted. A higher mRNA level of endothelin 1 (EDN1) (RQ>0.93; p=0.02) and Fas ligand (TNF superfamily, member 6; FASLG) (RQ>22.4; $\mathrm{p}=0.01)$ were associated with the risk for $\operatorname{IgAN}$ progression (RR 7.4 for EDN1, 6.7 for FASLG). In contrast, reduced risk of IgAN progression was observed in patients with up-regulation of the gene for vascular endothelial growth factor A $(V E G F)(\mathrm{RQ}>0.51 ; \mathrm{p}=0.01$; RR 13.3) (Fig. 4).

Using the GeneGO Metacore software (http://www.genego.com/) the analytical pathway map illustrating possible mechanisms of action of our markers in the IgAN progression was designed. Network illustrates possible role of EDN1, FASLG and VEGF in IgAN progression via routes leading to NF- $\kappa \mathrm{B}$ (map is not shown).

In the FSGS group, patients at risk of progression had lower expression of chemokine (C-C motif) ligand 19 (CCL19) mRNA (RQ<0.12, $\mathrm{p}=0.04$; RR 7.5) (Fig. 4).

There were no differences in clinical data between progressor and nonprogressor groups in both IgAN or FSGS groups at the time of biopsy, neither at 1 or 2 years follow-up. However, at 2 years, 4 out of 7 progressors in IgAN group developed end stage renal disease (Table 2).

\section{Discussion}

FSGS and IgAN represent the frequent glomerulopathies which may progress to ESRD. In the present study gene expression profiling of 90 immune related genes in patients with IgAN and FSGS was performed and potential molecular biomarkers for the progression of both glomerulopathies were identified.

The risk of IgAN progression at one year was associated with higher intrarenal expression of EDN1 and $F A S L G$ mRNA and lower expression of $V E G F$ mRNA. The progression of FSGS was associated with lower 
intrarenal expression of CCL19.

The role of EDN1 in the progression of chronic kidney diseases is well-known (Dhaun et al. 2012). It participates in podocyte dysfunction, inflammation and fibrosis and promotes mesangial cell proliferation and sclerosis. Increased staining for $E D N 1$ in endothelial cells of glomerular and peritubular capillaries was observed in patients with diabetic nephropathy and IgAN compared with controls (Zanatta et al. 2012). In our study, using the GeneGO Metacore software the possible involvement of $\mathrm{NF}-\mathrm{kB}$ signaling in glomerular injury in patients with IgAN progression was proposed. NF- $\mathrm{KB}$ signaling pathway in association with $E D N 1$ was also described on a mice model of diabetic glomerulosclerosis (Lenoir et al. 2014).

The decreased $V E G F$ expression in renal biopsies of various primary and secondary glomerulopathies was described in the sclerotic area, the area of marked amyloid deposition, and the area of crescent formation using immunohistochemistry and in situ hybridization. (Shulman et al. 1996) Lower VEGF expression in association with proteinuria was found in all investigated types of glomerulonephritides. (Donderski et al. 2013) This corresponds to our finding of lower $V E G F$ expression in renal tissue of (IgAN) patients with more rapid disease progression.

FASLG is involved in apoptotic cascades and probably participates in renal injury (Lorz et al. 2000). In situ hybridization and immunohistochemistry showed that proximal tubular epithelium is the main site of FasL expression in the normal kidney (Lorz et al. 2000). Up-regulation of mesangial FasL was observed by immunohistochemistry in proliferative lupus nephritis (Tsukinoki et al. 2004). The association of FASLG expression with IgAN has not been described yet. However, up-regulation of FASLG as risk factor of future IgAN progression may reflect the undergoing apoptosis. The association of CCL19 with FSGS progression has not been described yet as well.
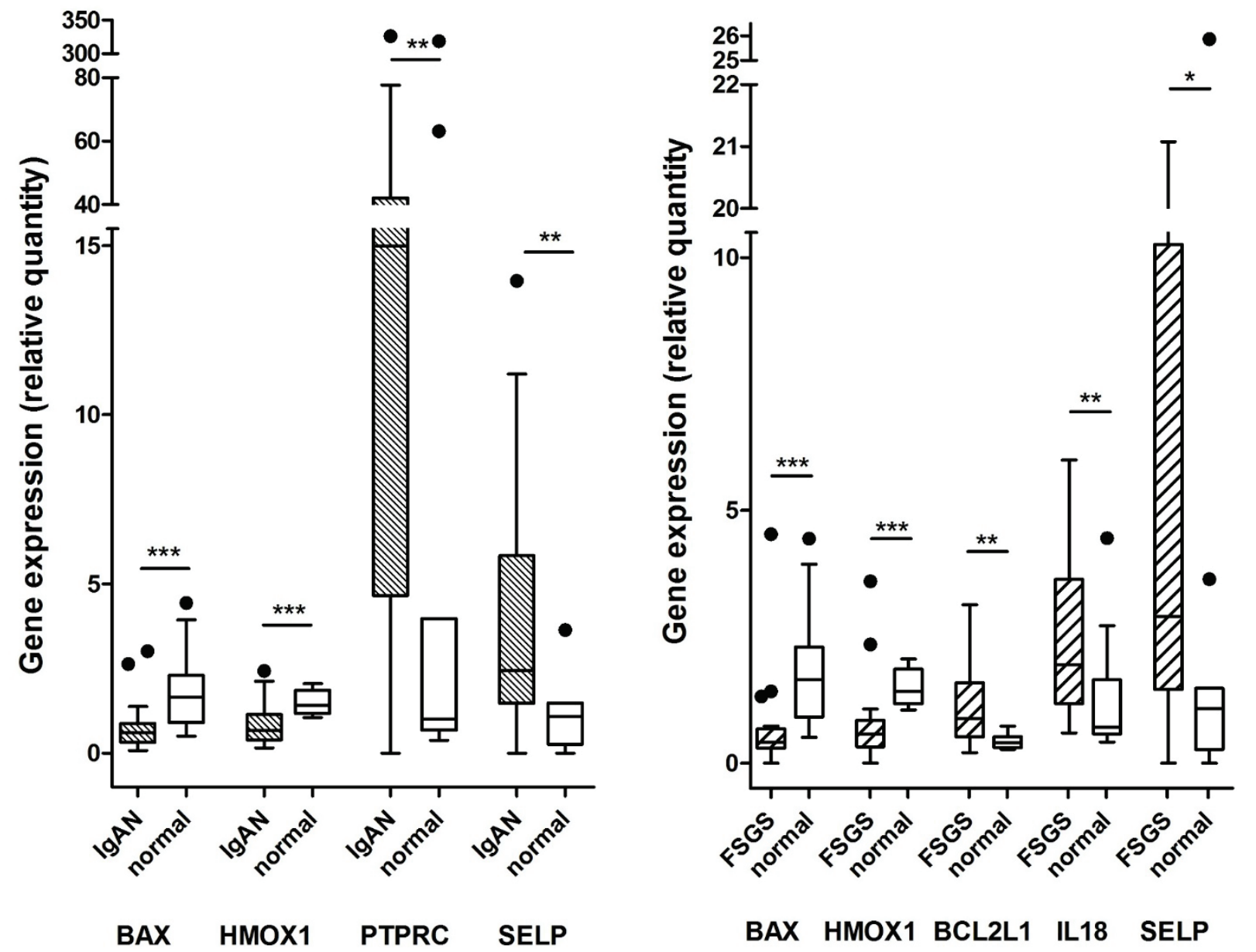

Fig. 2. Significant differences in gene expression profile among control group, IgAN and FSGS group. Differences between groups were calculated by Mann-Whitney test. $* p<0.05$, $* * p<0.01$ and $* * * p<0.001$. 
A

B
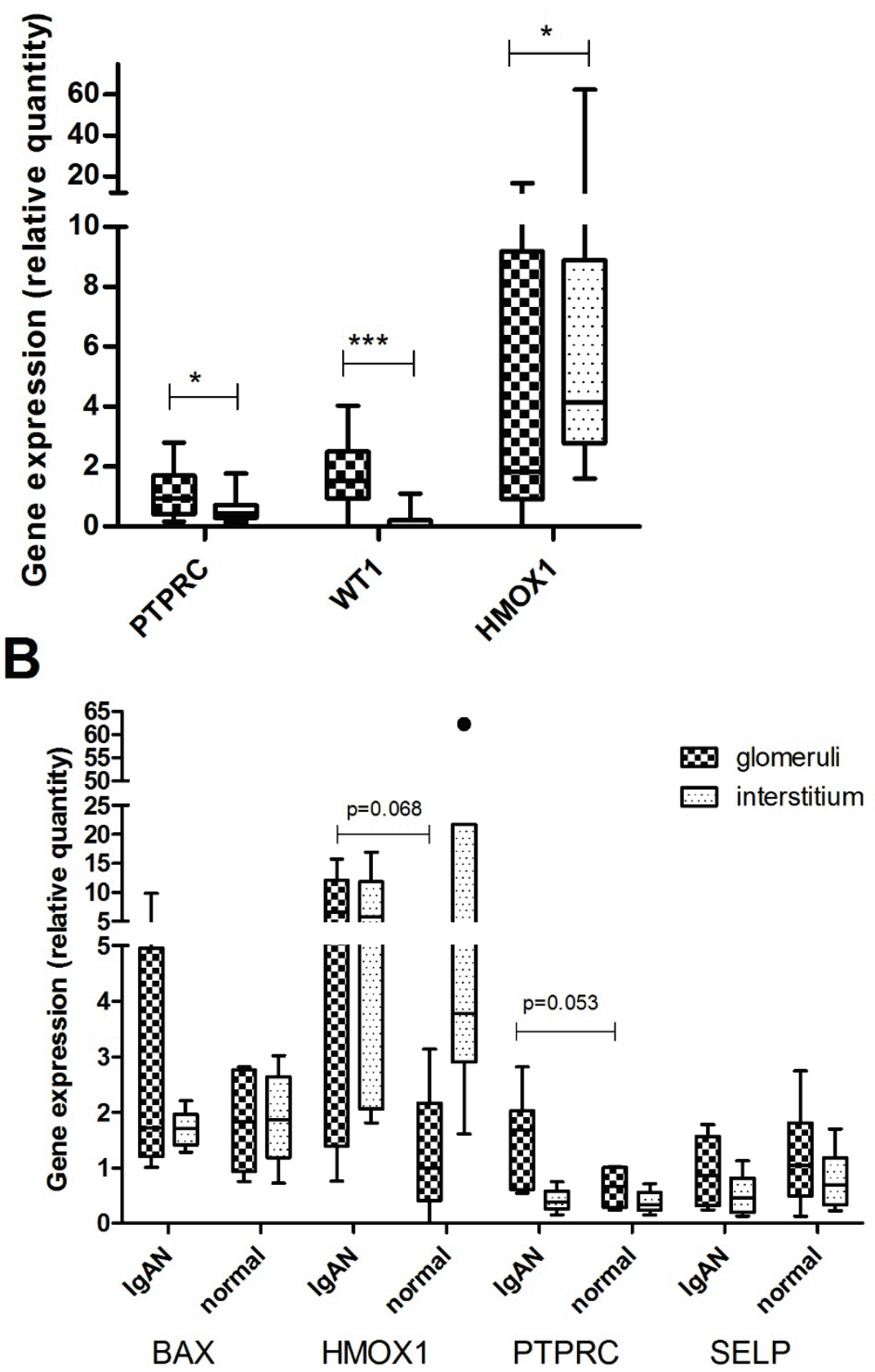

Fig. 3. (A) Significant differences in gene expression between glomeruli and interstitium in all patients regardless of diagnosis ( $n=32$ ) (IgAN, $\mathrm{n}=15$; controls, $\mathrm{n}=12$, FSGS, $\mathrm{n}=2$ ). (B) Gene expression of $B A X, H M O X-1$, PTPRC and SELP in microdissected glomeruli or in interstitium of patients with IgAN or controls. $* p<0.05$, $* * p<0.01$.

In our study we also evaluated the intrarenal expression profiles of the same set of genes in unaffected kidney in control group without glomerular and tubulointerstitial diseases. Significantly higher expression of $H M O X-1$ and $B A X$ and lower expression of SELP were observed in controls compared to IgAN or FSGS. $H M O X-1$ is an enzyme up-regulated during oxidative stress with anti-inflammatory effects. Higher $H M O X-1$ levels were found in urine samples of IgAN patients with interstitial cellular infiltration (Yokoyama et al. 2011). $B A X$ is involved in regulation of apoptosis and was found to be associated with progressive glomerular injury (Qiu et al. 2004). The elevated expression of HMOX-1 and $B A X$ have been reported in renal carcinomas (Balan et al. 2015, Gobe et al. 2002), however, the effect of cancer on the expression of both genes was minimalized as our control samples were taken from a healthy part of kidney clearly unaffected by a tumor. P-selectin (SELP) belongs 

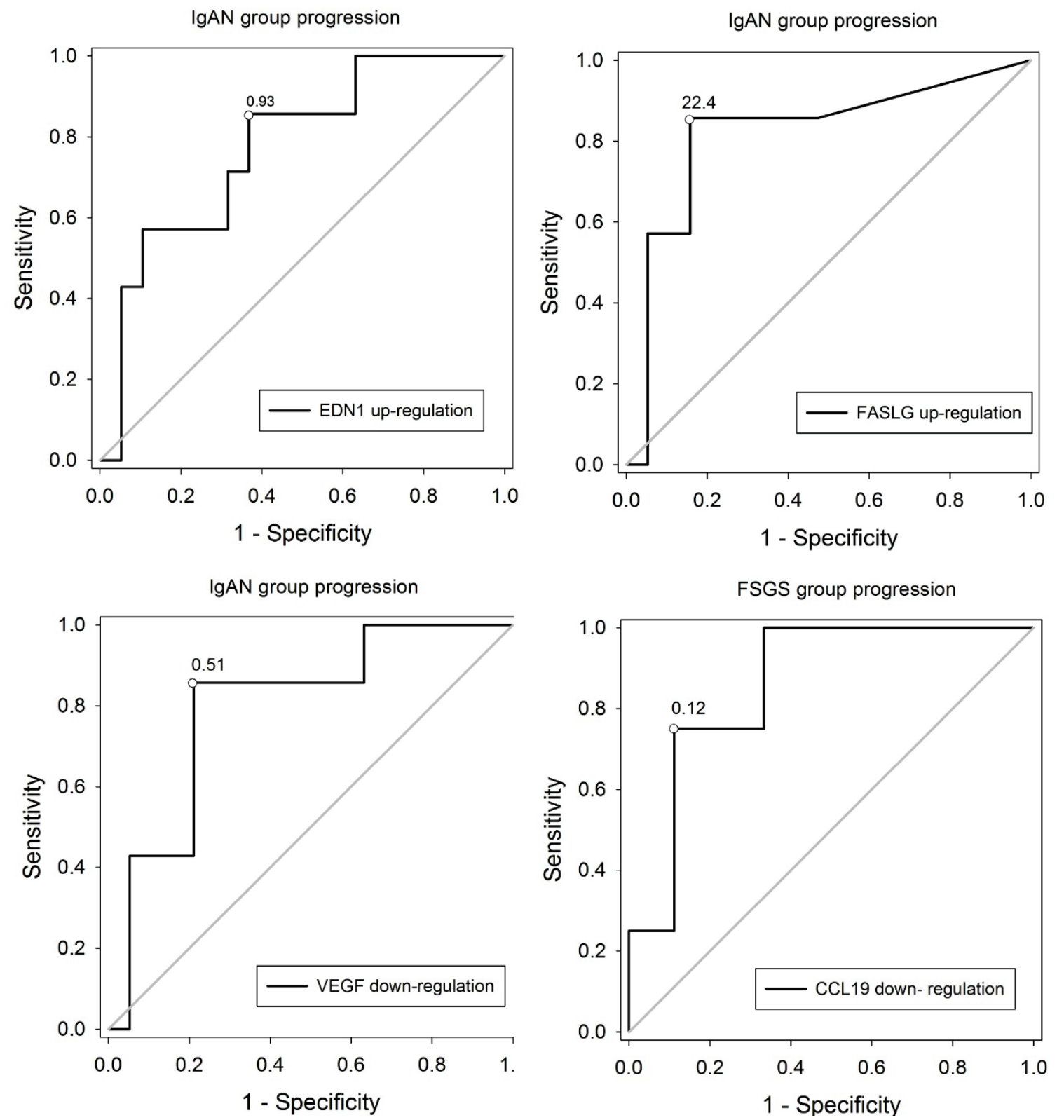

Fig. 4. Receiver operating characteristic (ROC) curves for progression of IgAN and FSGS disease according to gene expression. Regulation of these markers significantly determined the progression of IgAN or FSGS patients one year after diagnosis. (RQ cut-off point for EDN1 up-regulation $=0.93$; sensitivity $=86 \%$, specificity $=63 \%$, area under the curve (AUC) $=0.77, \mathrm{SE}=0.10$; RQ cut-off point for FASLG up-regulation=22.4; sensitivity $=86 \%$, specificity $=84 \%, \quad A U C=0.82, \quad S E=0.11 ;$ RQ cut-off point for VEGF down-regulation $=0.55$; sensitivity $=86 \%$, specificity $=79 \%, A U C=0.8, S E=0.10$; RQ cut-off point for CCL19 down-regulation=2.59; sensitivity $=75 \%$, specificity $=89 \%, \mathrm{AUC}=0.86, \mathrm{SE}=0.11$ ).

to adhesion molecules involved in leukocyte accumulation within the glomerulus. Association of SNP polymorphism in selectin genes and IgAN has been described (Takei et al. 2002). In addition, higher expression of PTPRC in IgAN and higher expression of ILI8 and BCL2L1 in FSGS compared to controls were found. The higher age of control group clearly limits generalization of our findings.

In this study, we further validated our observations using laser capture microdissection to focus separately on the glomerulus and interstitium. It is known, that primary injury both in IgAN and FSGS is localized to glomerulus. Nevertheless, glomeruli represent only a small part of biopsy and gene expression changes might be influenced by the expression in the surrounding tissue. For genes that are differentially expressed between glomeruli and interstitium, the changes between compared groups might be greatly influenced by their proportions in analyzed sample. Higher expression of $H M O X-1$ was confirmed by laser 
capture microdissection in interstitium which is in line with $H M O X-1$ staining within tubular epithelial cells (Morimoto et al. 2001). Two genes PTPRC and CD40 had significantly higher expression in glomeruli compared to interstitium. Validation of 4 differentially expressed genes between IgAN and controls in another patient's cohort by laser capture microdissection confirmed only the higher expression of PTPRC (CD45 surface marker of leukocytes) in glomeruli of IgAN patients. Higher expression of PTPRC probably reflects neutrophil infiltration into glomeruli.

In conclusion, a higher intrarenal expression of EDN1 and FASLG mRNA, lower intrarenal expression of $V E G F$ mRNA in IgAN patients and lower intrarenal expression of CCL19 mRNA in FSGS patients may help to identify patients at risk for future disease progression.
This observation might be used in the therapy modification and more intensive monitoring in patients at risk.

\section{Conflict of Interest}

There is no conflict of interest.

\section{Acknowledgements}

This work was supported by Ministry of Health, Czech Republic-conceptual development of research organization (Institute for Clinical and Experimental Medicine-IKEM, IN 00023001 and by grant LH 15168 from the Ministry of Education, Youth and Sports of the Czech Republic. The authors thank nurses and patients for their cooperation and help and Romana Polackova for expert technical assistance.

\section{References}

BALAN M, MIER Y TERAN E, WAAGA-GASSER AM, GASSER M, CHOUEIRI TK, FREEMAN G, PAL S: Novel roles of c-Met in the survival of renal cancer cells through the regulation of HO-1 and PD-L1 expression. J Biol Chem 290: 8110-8120, 2015.

BARBOUR SJ, ESPINO-HERNANDEZ G, REICH HN, COPPO R, ROBERTS IS, FEEHALLY J, HERZENBERG AM, CATTRAN DC: The MEST score provides earlier risk prediction in IgA nephropathy. Kidney Int 89: 167-175, 2016.

CHANDRAMOHAN K, MATHEWS A, KURIAN A, THOMAS S, RAMACHANDRAN K: Squamous cell carcinoma arising from perineal lesion in a familial case of Hidradenitis suppurativa. Int Wound J 6: 141-144, 2009.

COPPO R, TROYANOV S, BELLUR S, CATTRAN D, COOK HT, FEEHALLY J, ROBERTS IS, MORANDO L, CAMILLA R, TESAR V, ET AL.: Validation of the Oxford classification of IgA nephropathy in cohorts with different presentations and treatments. Kidney Int 86: 828-836, 2014.

COPPO R, TROYANOV S, CAMILLA R, HOGG RJ, CATTRAN DC, COOK HT, FEEHALLY J, ROBERTS IS, AMORE A, ALPERS CE, ET AL.: The Oxford IgA nephropathy clinicopathological classification is valid for children as well as adults. Kidney Int 77: 921-927, 2010.

DHAUN N, WEBB DJ, KLUTH DC: Endothelin-1 and the kidney--beyond BP. Br J Pharmacol 167: 720-731, 2012.

DONDERSKI R, SZCZEPANEK J, DOMAGALSKI K, TRETYN A, KORENKIEWICZ J, MARSZALEK A, SZYMANSKI A, WOLSKI Z, ODROWAZ-SYPNIEWSKA G, MANITIUS J: Analysis of relative expression level of VEGF (vascular endothelial growth factor), HIF-1alpha (hypoxia inducible factor 1alpha) and CTGF (connective tissue growth factor) genes in chronic glomerulonephritis (CGN) patients. Kidney Blood Press Res 38: $83-91,2013$.

GOBE G, RUBIN M, WILLIAMS G, SAWCZUK I, BUTTYAN R: Apoptosis and expression of Bcl-2, Bcl-XL, and Bax in renal cell carcinomas. Cancer Invest 20: 324-332, 2002.

KOOP K, EIKMANS M, BAELDE HJ, KAWACHI H, DE HEER E, PAUL LC, BRUIJN JA: Expression of podocyteassociated molecules in acquired human kidney diseases. J Am Soc Nephrol 14: 2063-2071, 2003.

KRONBICHLER A, LEIERER J, OH J, MEIJERS B, SHIN JI: Immunologic changes implicated in the pathogenesis of focal segmental glomerulosclerosis. Biomed Res Int 2016: 2150451, 2016.

LENOIR O, MILON M, VIRSOLVY A, HENIQUE C, SCHMITT A, MASSE JM, KOTELEVTSEV Y, YANAGISAWA M, WEBB DJ, RICHARD S, THARAUX PL: Direct action of endothelin-1 on podocytes promotes diabetic glomerulosclerosis. J Am Soc Nephrol 25: 1050-1062, 2014. 
LORZ C, ORTIZ A, JUSTO P, GONZALEZ-CUADRADO S, DUQUE N, GOMEZ-GUERRERO C, EGIDO J: Proapoptotic Fas ligand is expressed by normal kidney tubular epithelium and injured glomeruli. $J$ Am Soc Nephrol 11: 1266-1277, 2000.

MOLDOVEANU Z, WYATT RJ, LEE JY, TOMANA M, JULIAN BA, MESTECKY J, HUANG WQ, ANREDDY SR, HALL S, HASTINGS MC, ET AL.: Patients with IgA nephropathy have increased serum galactosedeficient IgA1 levels. Kidney Int 71: 1148-1154, 2007.

MORIMOTO K, OHTA K, YACHIE A, YANG Y, SHIMIZU M, GOTO C, TOMA T, KASAHARA Y, YOKOYAMA H, MIYATA T, ET AL.: Cytoprotective role of heme oxygenase (HO)-1 in human kidney with various renal diseases. Kidney Int 60: 1858-1866, 2001.

MORIYAMA T, TANAKA K, IWASAKI C, OSHIMA Y, OCHI A, KATAOKA H, ITABASHI M, TAKEI T, UCHIDA K, NITTA K: Prognosis in IgA nephropathy: 30-year analysis of 1,012 patients at a single center in Japan. PLoS One 9: e91756, 2014.

PLATZER C, ODE-HAKIM S, REINKE P, DOCKE WD, EWERT R, VOLK HD: Quantitative PCR analysis of cytokine transcription patterns in peripheral mononuclear cells after anti-CD3 rejection therapy using two novel multispecific competitor fragments. Transplantation 58: 264-268, 1994.

QIU LQ, SINNIAH R, I-HONG HSU S: Downregulation of Bcl-2 by podocytes is associated with progressive glomerular injury and clinical indices of poor renal prognosis in human IgA nephropathy. J Am Soc Nephrol 15: 79-90, 2004.

ROBERT T, BERTHELOT L, CAMBIER A, RONDEAU E, MONTEIRO RC: Molecular insights into the pathogenesis of IgA nephropathy. Trends Mol Med 21: 762-775, 2015.

ROBERTS IS, COOK HT, TROYANOV S, ALPERS CE, AMORE A, BARRATT J, BERTHOUX F, BONSIB S, BRUIJN JA, CATTRAN DC, ET AL:: The Oxford classification of IgA nephropathy: pathology definitions, correlations, and reproducibility. Kidney Int 76: 546-556, 2009.

SHULMAN K, ROSEN S, TOGNAZZI K, MANSEAU EJ, BROWN LF: Expression of vascular permeability factor (VPF/VEGF) is altered in many glomerular diseases. J Am Soc Nephrol 7: 661-666, 1996.

SCHMITT R, STAHL AL, OLIN AI, KRISTOFFERSSON AC, REBETZ J, NOVAK J, LINDAHL G, KARPMAN D: The combined role of galactose-deficient IgA1 and streptococcal IgA-binding M Protein in inducing IL-6 and C3 secretion from human mesangial cells: implications for IgA nephropathy. J Immunol 193: 317-326, 2014.

SCHWARTZ MM, EVANS J, BAIN R, KORBET SM: Focal segmental glomerulosclerosis: prognostic implications of the cellular lesion. J Am Soc Nephrol 10: 1900-1907, 1999.

STANGOU M, ALEXOPOULOS E, PAPAGIANNI A, PANTZAKI A, BANTIS C, DOVAS S, ECONOMIDOU D, LEONTSINI M, MEMMOS D: Urinary levels of epidermal growth factor, interleukin-6 and monocyte chemoattractant protein-1 may act as predictor markers of renal function outcome in immunoglobulin A nephropathy. Nephrology (Carlton) 14: 613-620, 2009.

TAKEI T, IIDA A, NITTA K, TANAKA T, OHNISHI Y, YAMADA R, MAEDA S, TSUNODA T, TAKEOKA S, ITO K, ET AL.: Association between single-nucleotide polymorphisms in selectin genes and immunoglobulin A nephropathy. Am J Hum Genet 70: 781-786, 2002.

TESTAGROSSA L, AZEVEDO NETO R, RESENDE A, WORONIK V, MALHEIROS D: Immunohistochemical expression of podocyte markers in the variants of focal segmental glomerulosclerosis. Nephrol Dial Transplant 28: 91-98, 2013.

TSUKINOKI T, SUGIYAMA H, SUNAMI R, KOBAYASHI M, ONODA T, MAESHIMA Y, YAMASAKI Y, MAKINO H: Mesangial cell Fas ligand: upregulation in human lupus nephritis and NF-kappaB-mediated expression in cultured human mesangial cells. Clin Exp Nephrol 8: 196-205, 2004.

VIKLICKY O, KRYSTUFKOVA E, BRABCOVA I, SEKERKOVA A, WOHLFAHRT P, HRIBOVA P, WOHLFAHRTOVA M, SAWITZKI B, SLATINSKA J, STRIZ I, ET AL.: B-cell-related biomarkers of tolerance are up-regulated in rejection-free kidney transplant recipients. Transplantation 95: 148-154, 2013.

YOKOYAMA T, SHIMIZU M, OHTA K, YUNO T, OKAJIMA M, WADA T, TOMA T, KOIZUMI S, YACHIE A: Urinary heme oxygenase-1 as a sensitive indicator of tubulointerstitial inflammatory damage in various renal diseases. Am J Nephrol 33: 414-420, 2011. 
ZANATTA CM, VERONESE FV, LORETO MDA S, SORTICA DA, CARPIO VN, ELDEWEISS MI, DA SILVA VD, LOPES TG, GROSS JL, CANANI LH: Endothelin-1 and endothelin a receptor immunoreactivity is increased in patients with diabetic nephropathy. Ren Fail 34: 308-315, 2012.

ZHAO Y, ZHU L, ZHOU T, ZHANG Q, SHI S, LIU L, LV J, ZHANG H: Urinary CXCL1: a novel predictor of IgA nephropathy progression. PLoS One 10: e0119033, 2015. 